\title{
Factors influence ease of use on Fintech adoption: Mediating by the role of attachment anxiety under Covid-19 pandemic
}

\author{
Le Thi Hong Minh ${ }^{1 *}$ \\ ${ }^{1}$ University of Economics Ho Chi Minh City, Vietnam \\ *Corresponding author: minhlth@ueh.edu.vn
}

\begin{abstract}
ARTICLE INFO
ABSTRACT

DOI: $10.46223 / \mathrm{HCMCOUJS.}$

econ.en.11.2.1799.2021

Received: April 12 $2^{\text {th }}, 2021$

Revised: May $25^{\text {th }}, 2021$

Accepted: May $28^{\text {th }}, 2021$

Keywords:

attachment anxiety; consumer belief; Covid-19 pandemic;

Fintech; security and privacy

In recent times, Fintech has developed rapidly along with the development of technology. The Covid-19 lockdown has created a huge opportunity in terms of increasing the number of users, and users' experience. Previous studies have shown a number of factors affecting the use of financial technology services. However, what are the factors that are caused by the Covid-19 epidemic, and the ability to enhance competitive advantage and retain users is still lacking. Data were collected in Vietnam, comprising 247 respondents, and the SEM model was used to predict the effects. This study shows that users' users' beliefs, security and privacy, web design of Fintech services, customer value, and attachment anxiety during prolonged lockdown without a feasible solution to date increase intention to adopt Fintech. Both theoretical and practical applications were discussed in this study.
\end{abstract}

\section{Introduction}

The availability of the Internet and mobile information has become indispensable in modern life, creating a vast market for digital financial services. As a combination of technology and finance, Fintech does become a form of financial innovation in the digital era. Financial innovation can be called new products, new services, new production processes, or organizations (Lee, Li, Yu, \& Zhao, 2021). Fintech includes digital bank balance checks, payments, and account transactions (Kang, 2018). It creates opportunities for users to perform financial transactions while still staying at home. During the Covid-19 pandemic, shops and borders closed, and Fintech accelerated at a speedy rate (Talwar, Dhir, Khalil, Mohan, \& Islam 2020). It opens a considerable chance for Fintech firms; however, it is also competitive among Fintech services to attract and maintain users.

Vietnam ranks second as ASEAN in funding fintech activities, attracting $36 \%$ of the region's total investment in Fintech in 2019. Vietnam is experiencing a boom in digital payments, and e-commerce significantly increases in the context of Covid-19 lockdown. In the first quarter of 2020 , e-payments increased by $76 \%$, of which the total transaction value increased by $124 \%$ compared to the first quarter of 2019 (Asian Development Bank, 2019). This is an unprecedented growth, in which payment via mobile wallet MoMo has more than doubled since February. E-commerce activity has also grown significantly this year due to the epidemic, with total visits to shopping apps reaching 12.7 billion in the second quarter of 2020 and an increase of $43 \%$ quarter-to-quarter. In addition, Vietnamese banks have accelerated digital adoption, partnering with fintech companies to enhance related financial transactions (Nguyen, Doan, \& Bui, 2020). 
Previous research has shown that users accept Fintech and mainly rely on peer influences, data security, and privacy (Vučinić, 2020), perceived usefulness (Chuang, Liu, \& Kao, 2016). The online market grows rapidly and provides mobile devices, the demand for mobile Fintech payment services that enable easy online and offline payments has increased (Kang, 2018). Even though this is an emerging market, but it is competitive; therefore, it requires combined factors to attract users and maintain the existent consumers. To become popular and be adopted by most users, Fintech services need to be easy to use (Chuang et al., 2016). Combined with the force majeure situation is Covid-19, users want an easy-to-use service, eye-catching design, but also easy to understand, fast, diversified products, benefiting themselves. During the Covid-19 pandemic, consumers use Fintech to make sure their purchases occur normally. Also, it can be a way to keep them busy since most of us can't get out and suddenly have too much time to spend, as well as we are living in an anxiety situation (Peteet, 2020). Pandemic and anxiety cause mental health issues and loneliness. Consumers figured out different ways to in touch with the outside world to reduce their stress. One way is to use financial technology to online shopping because shopping is hedonic motivation to release stress (Horváth \& Adigüzel, 2018).

Previous research has not focused on the relationship between anxiety and buying behavior that will be enhanced by the convenience of Fintech adoption. In addition, the relationships between Fintech web design, Fintech services, security and privacy, and consumer value that could increase Fintech usage during Covid-19 will be assessed. This study identified factors that increase consumer perceived ease of use and the role of attachment anxiety in raising Fintech adoption rates during the Covid-19 pandemic.

\section{The technology acceptance model}

Theory adopts the technology model developed by Davis (1989). This theoretical content includes the ease of use and the usefulness of the technology, which will affect the intent to use and use the technology (Davis, 1989). Behavioral intent is a factor that leads to people using a technology, influenced by the user's behavior and impression of the technology. The actual use of the system is the endpoint where people use technology. Behavioral intent is a factor in people's use of technology. Perceived usefulness, defined by Davis $(1989$, p. 5) as "the degree to which a person believes that using a particular system will improve their productivity." Users find the technology useful, which makes them want to use it. Perceived ease of use was defined as "the degree to which one believes using a particular system will be effortless" (Davis, 1989, p. 7). Find out what factors are considered to ease of use for Fintech. If the technology is easier to use, more customers want to use it, including a simple and convenient interface and desired tools.

\subsection{Fintech services belief and perceived ease of use}

Previous research has shown that mindsets are positively related to the individual. When a person has a positive experience in Fintech products and services, which enhances consumers' belief toward the service (Kim, Lee, Mun, \& Johnson, 2017), and in return, the readiness level increases (Chuang et al., 2016). Likewise, users' thoughts have a big impact on the perceived ease of use of financial apps (Trivedi, Patel, \& Acharya, 2018). Furthermore, users' beliefs influence the perceived ease of use of online banking (Lee, Park, Chung, \& Blakeney, 2012). The positive approach toward Fintech is based on users' real need for Fintech (Chuang et al., 2016). The reality is that pandemics make it impossible for people to go out and shop as they wish; they need a reliable, remote means of payment to maintain daily activities, as well as other needs (Fu \& Mishra, 2020). Customer confidence in Fintech services is obtained from several previous experiences, reviews on apps or websites, and the network of connections between friends, relatives, or private communities (Kang, 2018). The client believes that Fintech is a good choice for financial services, especially during Covid-19 lockdown (Fu \& Mishra, 2020). All 
everyday transactions can be done at home, easily and conveniently (Billore \& Billore, 2020). It is the ease of operations and transactions, plus the reliability of account security, information, and the ability to link with many other third parties that the trust is fostered and strengthened (Gai, Qiu, Sun, \& Zhao, 2016; Stewart \& Jürjens, 2018). That's why Fintech is a perfect choice for everyone at this pandemic time, so the user's belief will be positive towards this service (Wójcik \& Ioannou, 2020). Besides, due to previous experience, if Fintech is easy to use, the approach of users will be more positive, and using Fintech can become a normal daily activity (Fu \& Mishra, 2020). With the above evidence, it is possible to hypothesize the Fintech services belief leading to perceived ease of use.

\section{H1: Fintech services belief has a positive impact on perceived ease of use}

\subsection{The Fintech services website design and perceived ease of use}

The study examines the relationship between website elements and their impact on user intentions, online behavior, and user satisfaction (Bauer, Falk, \& Hammerschmidt, 2006). Web design elements constitute the main drivers of online behavior (Dickinger \& Stangl, 2013). Site quality, user perceptions, as well as the site's features to meet the needs of the customer, will increase perceived ease of use, reflect satisfaction and increase user intent (Dennis, Merrilees, Jayawardhena, \& Tiu Wright, 2009). Components to improve website quality include technicality, security, ease of navigation, searchability, usability, valid links, personalization, or customization, page loading speed, interaction, and ease to access (Aladwani, 2006). The second element is the website's general content, which includes useful, complete, clear, concise, and accurate content. The third element is specific content, including contact information, user policies, and customer support. The final factor is how the website looks (DeLone \& McLean, 2003). A well-designed website will include the above elements but should always be easy to use for all types of customers.

\section{H2: The Fintech services website design has a positive impact on perceived ease of use}

\subsection{Data security and privacy toward the financial services, design, and perceived ease} of use

Privacy policy and data privacy are one of the key factors for consumers to adopt digital financial services (Stewart \& Jürjens, 2018). By downloading and installing apps, smartphone users increase the risks associated with design errors, malware attacks, and data theft. Users are concerned that their personal information and bank accounts (Barth, de Jong, Junger, Hartel, \& Roppelt, 2019) will be leaked or stolen. Despite the concerns of many users, the number of mobile app downloads worldwide continues to increase (Gai et al., 2016). The security and privacy of Fintech services are key factors for users to trust and choose services (Li, Dai, Park, \& Park, 2017). If customers feel their confidential information is protected, this will increase their desire to continue using their services (Lim, Kim, Hur, \& Park, 2019). Thus, Fintech services with highly secure data security systems will surely attract users' trust and retain long-term customers (Nangin, Barus, \& Wahyoedi, 2020). Therefore, we formulate the following hypothesis.

\section{H3: Security and privacy have a positive impact on perceived usefulness toward Fintech}

\subsection{Consumer value and perceived ease of use}

According to consumer value theory, it refers to value perception is an important predictor of brand loyalty (Sweeney \& Soutar, 2001). Consumer value is defined as the important personal goals that consumers are seeking (Lai, 1995). Consumers stick with a service or a brand if their identification connection with the attributes of the service or the brand 
(Sreejesh \& Roy, 2015), which relates to the convenience in using (Alalwan, Dwivedi, Rana, \& Williams, 2016). Ease of use is one of the most important features of technological services, especially the middle age and above (Persaud \& Azhar, 2012). From a consumer value perspective, the impact of perceived value in purchasing through Fintech services is tied to the benefits and sacrifices they make (Ponte, Carvajal-Trujillo, \& Escobar-Rodríguez, 2015). The less this trade-off, and the more benefits and benefits the user will maintain in the long term (Lai, 1995). Previous studies suggested that the most consumer-valued aspects in the electronic banking services are better service quality (Howcroft, Hamilton, \& Hewer, 2002), 24-hour service availability (Gerrard \& Cunningham, 2003), time savings (Karjaluoto, Mattila, \& Pento, 2002), ease of use (Joseph, McClure, \& Joseph, 1999; Moutinho \& Smith, 2000). This study evaluated the role of customer value in ease of use.

\section{H4: Consumer value have a positive impact on perceived of ease of use}

\subsection{Perceived of ease of use and Intention to adopt Fintech}

The operational definition of perceived usefulness is the belief in the degree of ease of using the Fintech service (Davis, 1989). The list of attributes of perceived usefulness was selected from the scale developed by (Davis, 1989). Fintech services bring benefits to everyone, for example, increasing completion of work tasks, reducing travel time, and reducing excess paperwork (Chuang et al., 2016; Lee, Ryu, \& Lee, 2019). Recognizing the usefulness of Fintech, especially during the Covid-19 pandemic, will help users realize the importance of such services (Billore \& Billore, 2020). Usefulness includes many factors, such as usability, the ability to secure the information, and satisfaction with the quality of service. The pandemic situation may have an impact on whether the user will continue to use Fintech (Revathy \& Balaji, 2020). However, the Covid-19 pandemic is an opportunity to promote positive experiences. Consequently, it enhances users' attitudes toward Fintech after a certain amount of time (Huei, Cheng, Seong, Khin, \& Bin, 2018; Jiwasiddi, Adhikara, Adam, \& Triana, 2019). We, therefore, formulated the following hypothesis.

Ease of use of Fintech or technology, in general, is an important feature outlined in the TAM model (Davis, 1989). Users are more likely to use technologies, especially financial technologies, when that technology is easier to use, convenient, and safe. Ease of use includes many factors such as having the right tools as expected, the design is easy to identify and use, bringing useful value to consumers (reducing travel time, less system failure, low fees, reduce redundant paperwork, etc.). Fintech products are not only limited to young people, technology lovers but also extend to many ages and different income levels. Therefore, the easier it is to use, the more users increase the use of Fintech. Therefore, we hypothesize:

\section{H5: Perceived usefulness positively impacts intention to adopt Fintech}

\subsection{The mediating role of attachment anxiety during the Covid-19 pandemic}

Attachment anxiety refers to the anxiety you experience about your relationships with other important people, including your parents, friends, and objects (Eastwick \& Finkel, 2008). Attachment anxiety often stems from previous experiences but can extend into the new situation and negatively affect all relationships if not addressed properly (Irons \& Gilbert, 2005). Experiences like attachment anxiety will play an important, functional role in the opening stages of seeking the way to release the anxiety feelings (Simpson, Rholes, \& Nelligan, 1992). According to Liu, Yang, Zhu, and Zhang (2019), loneliness can cause anxiety, and individuals tend to find ways to interact with just about any object. The Stimulus-Organism-Response (SOR) framework indicates that psychological distance can cause anxiety (Cao \& Sun, 2018). Lockdown decreased psychological distancing that sequentially reassured anxiety (Kim, 2019), 
psychological disorders such as depression in residents (Rodríguez-Hidalgo, Pantaleón, Dios, \& Falla, 2020). For instance, Severe Acute Respiratory Syndrome (SARS) triggered anxiety and social difficulties (Rubin, Coplan, \& Bowker, 2009). During the Covid-19 course, individuals desire to come into contact with the outside world, interact with people, and want to return to normal life (Luchetti et al., 2020), which can cause mental health problems (Prati \& Mancini, 2021). However, even at home, people still need to buy food, essential products, and entertainment activities (Dolbeault \& Turinici, 2020). They tend to use technology financial services to keep purchases going, creating an intrinsic motivation to adopt Fintech (Venkatesh, 2000). Besides, the easy-to-use Fintech service supports them to use Fintech as a payment method to increase social interaction and relieve anxiety while Covid-19 is locked (Darmansyah, Fianto, Hendratmi, \& Aziz, 2020). Users tend to apply technology to adapt to the new situation, especially when Fintech is easy to use (Alalwan et al., 2016). Users' attachment anxiety relates to their worry of prolonged malaise and are looking for a technological solution for social distance rule, as well as reducing potential disease risks. Since users recognize Fintech is easy to use, can be a supportive tool to release their anxiety, then attachment anxiety can relate to perceived ease of use (Saadé \& Kira, 2007). Thus, the easier it is to use, the more users will increase their intention to use Fintech, especially in the Covid context, as a way of increasing social interaction and reducing feelings of anxiety, and increasing connection (Davis, 1989; Nangin et al., 2020; Venkatesh, 2000). Thus, we assume that:

H6: The attachment anxiety during Covid-19 pandemic mediates the relationship between perceived ease of use and intention to adopt Fintech

\subsection{The impact of Gender in multi groups on intention to use Fintech}

Gender differences in business intentions are explained by individual attitudes. Gender differences within perceived behavioral control and personal attitude are investigated (Maes, Leroy, \& Sels, 2014). However, previous studies have not looked at gender differences in fintech use, and the effect of anxiety caused by Covid-19 on the desire to increase social interaction. This study will examine the effects of gender on the above relationships. The research model is shown in Figure 1.

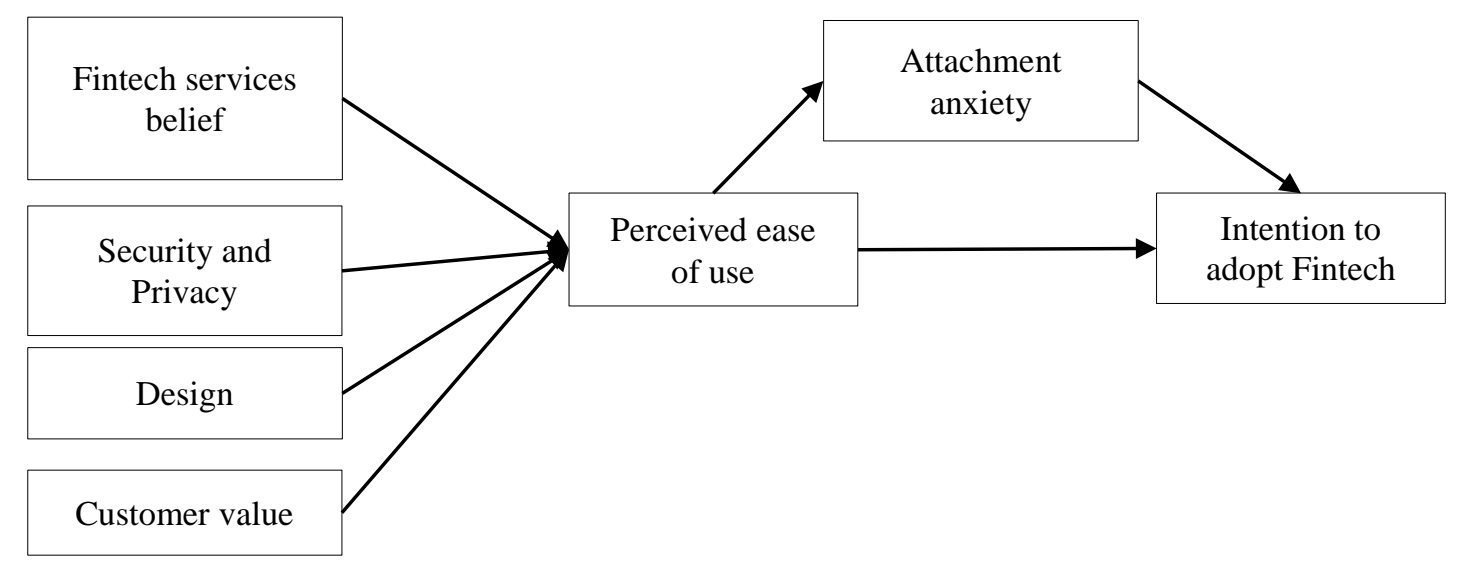

Figure 1. The research model

\section{Research Methodology}

\subsection{Data collection}

We have developed an open survey via Google Forms. We conducted a pilot test on 10 students as a convenient sample to test the intelligibility of the questions. After doing some main 
things as reflected by the test respondents (e.g., some grammatical errors), we proceeded with large numbers. Subjects are people over 18 years old, residing in Vietnam and regularly using Fintech. In order to correctly identify the research object, a filter question was used: "Do you use Fintech service or not?" If the answer is "No", the respondent will be thanked for participating. If the answer is "Yes", the respondent will be invited to answer follow-up questions. Participants answer all questions within one to three minutes.

Data from 247 respondents were used to test the proposed model, with an efficiency rate of $99.2 \%$ because we have eliminated 02 responses because they have replied "No" for using Fintech during Covid-19 lockdown. According to the 10-fold rule, the minimum sample size for the PLS-SEM should be 70 for seven constructs. Each variable measured must have at least 10 cases for (1) the number of indicators in the largest latent factor block or (2) the largest number of causal arrows comes for any potential variable in the model (Hair, 2014). The demographic characteristics of respondents are reported in Table 1 . The data includes more women $(69.5 \%)$ than men (30.5\%), most (61.94\%) less than 35 age and the majority have a higher education level $(65.8 \%)$. In terms of occupation, professionals $(48.2 \%)$ accounted for the highest proportion, followed by white-collar workers (19.8\%). Fintech usage frequency was 39.8\%, followed by "regular" (31.7\%) (see Table 1).

\section{Table 1}

Descriptive statistics for users' groups

\begin{tabular}{cccc}
\hline Demographics & & $\mathbf{N}=\mathbf{2 4 9}$ & \% \\
\hline \multirow{2}{*}{ Gender } & Male & 114 & 45.8 \\
& Female & 135 & 54.2 \\
\hline \multirow{2}{*}{ Age } & $18-25$ & 99 & 39.8 \\
& $26-35$ & 79 & 31.7 \\
& $36-45$ & 27 & 10.8 \\
& $46-55$ & 28 & 11.2 \\
& $56-65$ & 11 & 4.4 \\
Education & Over 65 & 5 & 2.0 \\
& Vocational/College & 19 & 7.6 \\
& Undergraduate & 164 & 65.9 \\
& Postgraduate & 66 & 26.5 \\
\hline & Students & 3 & 1.2 \\
& Service industry proprietors & 40 & 16.1 \\
& Professionals & 119 & 47.8 \\
& White-colars & 49 & 19.7
\end{tabular}




\begin{tabular}{cccc}
\hline Demographics & & $\mathbf{N}=\mathbf{2 4 9}$ & $\mathbf{\%}$ \\
\hline \multirow{3}{*}{ Computer skill } & Basic & 7 & 2.8 \\
& Intermediate & 50 & 20.1 \\
& Advanced & 130 & 52.2 \\
& Expert & 62 & 24.9 \\
\hline \multirow{2}{*}{ Income } & Under 5 million VND/month & 21 & 8.4 \\
& $5-10$ million VND/month & 65 & 26.1 \\
& $10-15$ million VND/month & 116 & 46.6 \\
& Over 15 million VND/month & 47 & 18.9 \\
\hline
\end{tabular}

Source: Data analysis results

\subsection{Procedure development}

The construct items use those from previous research on mobile banking services. The scale items are measured on a five-point Likert scale ( $1=$ strongly disagree to $5=$ strongly agree) (see Table 2). Customer value was evaluated using three items adapted from Sirdeshmukh, Singh, and Sabol (2002) (i.e., This Fintech service help me save money). Data privacy and security were evaluated using six items adapted from Stewart and Jürjens (2018) (i.e., I believe that Fintech of this financial services is probably one of the best places to put my money.) The Fintech services website design were evaluated using three items adopted from Blut (2016) (i.e., The Fintech website is visually pleasing). Fintech services belief were evaluated using three items adopted from Isaac, Brough, and Grayson (2016) (i.e., If I needed to open a financial service, Fintech would be an excellent choice). Attachment anxiety by Covid19 Impact were evaluated using four items adopted from Collins and Read (1990) (i.e., I worry about being alone due to Covid19 pandemic). Perceived ease of use was evaluated using four items adopted from Davis, Bagozzi, and Warshaw (1989) (i.e., I worry about being alone due to Covid19 pandemic). Intention to adopt Fintech were evaluated using five items adopted from (Chuang et al., 2016) (i.e., I intend to use Fintech services).

\section{Analysis and results}

\subsection{Measurement model}

Data collected from the same source may lead to potential common method variance. We used Harman's single-factor tests to examine this type of bias (Podsakoff, MacKenzie, Lee, \& Podsakoff, 2003). The results indicate five factors with eigenvalues larger than one, and the first factor accounts for $30.247 \%$ of the total variance. The results suggest that common method bias is not a concern for the data.

The Cronbach's $\alpha$ values and the composite reliability values were greater than the 0.5 threshold value (Fornell \& Larcker, 1981), thus confirming good reliability. The factor loadings of items were also above 0.5 , indicating good convergent validity (Hair, Sarstedt, Hopkins, \& Kuppelwieser, 2014; Gerbing \& Anderson, 1992) (see Table 2).

The discriminant validity of the constructs was confirmed by the square root of the average variance attracted being greater than any of the inter-construct correlations (Fornell \& Larcker, 1981) (see Table 3). The HTMT criterion was significantly smaller than 01 or below 01 , thus indicating the distinctiveness of the constructs (Henseler, Ringle, \& Sarstedt, 2015) (see Table 4). 


\section{Table 2}

Measurement model resulting from confirmation factor analysis

\section{Constructs and variables}

Customer value

CV1 This mobile financial service help me save money

CV2 This mobile financial service is a "good deal" for me

CV3 This mobile financial service provides me the value Security and Privacy

SP1 I trust in the technology a mobile financial service is using

SP2 I trust in the ability of a mobile financial service to protect my privacy

SP3 I trust in a mobile financial service as a bank

SP4 Using a mobile financial service is financially secure

SP5

I am not worried about the security of a mobile financial service

SP6

When a mobile financial service promises to do something by a certain time, it does so

\section{Attachment anxiety by Covid19 Impact}

AE1 I worry about being alone due to the Covid-19 pandemic

AE2

When I'm not involved in a relationship, I feel somewhat

anxious and insecure during the Covid19 pandemic

I worry that people I have relationships with won't care

AE3 about me as much as I care about them due to the Covid-19 pandemic

AE4

My desire to be very close sometimes scares people away

due to the Covid-19 pandemic

\section{Perceived ease to use}

EU1

Using mobile financial service helps me online purchasing more quickly

EU2 Using mobile financial service enhances my online purchasing effectiveness

EU3

Using mobile financial service makes it easier to do my online purchasing

EU4 Overall, using mobile financial services is useful

Intention to adopt Fintech

\section{Factor loadings $\quad \alpha$}

0.876

0.890

0.916

0.876

0.858

0.808

0.792

0.780

0.794

0.699

0.710

0.816

0.828

0.810

0.861

0.707

0.801

0.833 


\section{Constructs and variables}

IU1 I intend to use mobile financial services

IU2 I predict I will use mobile financial services

IU3 I plan to use mobile financial services

0.866

IU4 I will strongly recommend using mobile financial services to others

IU5 If I have access to mobile financial services, I want to use them as much as possible

\section{The Fintech services website design}

DE1 The Fintech website is visually pleasing

DE2 The Fintech website displays a visually pleasing design

DE3 The Fintech website is visually appealing

0.863

\section{Fintech services belief}

FS1 If I needed to open a financial service, Fintech would be an excellent choice

FS2 I would feel confident banking at Fintech service

FS3

I believe that this Fintech service is probably one of the best places to put my money
0.825

0.818

Notes: $\alpha$ - Cronbach alpha; Factor loadings should be larger than 0.5 (Hair, 2014)

Source: Data analysis results

\section{Table 3}

Construct Reliability and Validity

\begin{tabular}{lccccccccc}
\hline & CR & AVE & AE & CV & DE & EU & FS & IU & SP \\
\hline AE & 0.879 & 0.646 & 0.804 & & & & & & \\
CV & 0.923 & 0.800 & 0.369 & 0.894 & & & & & \\
DE & 0.889 & 0.727 & 0.510 & 0.348 & 0.853 & & & & \\
EU & 0.872 & 0.630 & 0.449 & 0.478 & 0.515 & 0.794 & & & \\
FS & 0.876 & 0.702 & 0.449 & 0.412 & 0.501 & 0.548 & 0.838 & & \\
IU & 0.935 & 0.743 & 0.293 & 0.073 & 0.083 & -0.114 & 0.021 & 0.862 & \\
SP & 0.894 & 0.585 & 0.402 & 0.394 & 0.445 & 0.566 & 0.473 & 0.034 & 0.765 \\
\hline
\end{tabular}

Notes: CR: Composite Reliability; AVE: Average variance extracted; AE: Attachment anxiety by Covid-19 Impact, CV: consumer value, DE: The Fintech services website design; EU: Perceived of ease to use; FS: Fintech services belief; IU: Intention to use; SP: Security and Privacy

Source: Data analysis results 


\section{Table 4}

Heterotrait - monotrait ratio

\begin{tabular}{lcccccccc}
\hline & AE & CV & DE & EU & FS & IU & SP & Was the HTMT less than 01? \\
\hline AE & & & & & & & & \\
CV & 0.435 & & & & & & Yes \\
DE & 0.624 & 0.412 & & & & & Yes \\
EU & 0.549 & 0.555 & 0.635 & & & & Yes \\
FS & 0.556 & 0.505 & 0.621 & 0.683 & & & Yes \\
IU & 0.335 & 0.123 & 0.102 & 0.133 & 0.089 & & Yes \\
SP & 0.480 & 0.448 & 0.533 & 0.678 & 0.577 & 0.075 & Yes \\
\hline
\end{tabular}

Notes: AE: Attachment anxiety by Covid-19 Impact, CV: consumer value, DE: The Fintech services website design; EU: Perceived of ease to use; FS: Fintech services belief; IU: Intention to adopt Fintech; SP: Security and Privacy Source: Data analysis results

The analysis featured partial least squares structural equation modelling (PLS-SEM) using SmartPLS v3.2.8 showing the fit of the measurement model was evaluated by the

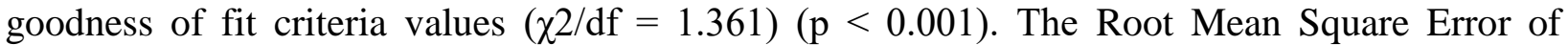
Approximation (RMSEA) is $0.038<0.08$, the Comparative Fit Index (CFI) is $0.965>0.800$, the Normed Fit Index (NFI) is $0.882>0.800$, and the Tucker - Lewis coefficient TLI (rho2) is 0.960 $>0.800$, Standardized Root Mean Square Residual (SRMR) is .0418<0.08.

\subsection{Structural model}

The maximum likelihood is used to assess the fit parameters. The model shows good fit with the data $(\chi 2 / \mathrm{df}=2.088, \mathrm{CFI}=0.891$, TLI $=0.880, \mathrm{RMSEA}=0.066, \mathrm{p}<0.01)$ (Hair et al., 2014). The index shows a Goodness-Of-Fit Index (GFI) of 0.821, and the Bentler and Bonett (1980), Normed Fit Index (NFI) shows a Goodness-Of-Fit Index (GFI) of 0.821. The VIF is less than 5 ; then, there are no problems between the constructs' collinearity predictions in the structural model (Hair, 2014) (see Table 5).

Table 5 showed the Stone - Geisser test of predictive relevance $\left(\mathrm{Q}^{2}\right)$ for Attachment anxiety by Covid-19 Impact was .121, intention to adopt Fintech was .107, and perceived ease of use was .288, which meant that the research model was predictably relevant (Hair, Sarstedt, Matthews, \& Ringle, 2016) (see Table 5).

\section{Table 5}

The Stone - Geisser test of predictive relevance $\left(Q^{2}\right)$

\begin{tabular}{llccc}
\hline & \multicolumn{1}{c}{ Construct } & SSO & SSE & $\mathbf{Q}^{\mathbf{2}}$ \\
\hline AE & Attachment anxiety by Covid-19 Impact & 996.000 & 875.833 & 0.121 \\
CV & Consumer value & 747.000 & 747.000 & \\
DE & The Fintech services website design & 747.000 & 747.000 & \\
EU & Perceived of ease to use & 996.000 & 709.371 & 0.288 \\
FS & Fintech services belief & 747.000 & 747.000 & \\
IU & Intention to adopt Fintech & $1,245.000$ & $1,111.279$ & 0.107 \\
SP & Security and Privacy & $1,494.000$ & $1,494.000$ & \\
\hline
\end{tabular}

Notes: SSO: Sum of squares of observations; SSE: Sum of squared errors; AE: Attachment anxiety by Covid-19 Impact, CV: consumer value, DE: The Fintech services website design; EU: Perceived of ease to use; FS: Fintech services belief; IU: Intention to adopt Fintech; SP: Security and Privacy

Source: Data analysis results 
The final step in the data analysis was to assess the structural model by examining the path significance, effect of each hypothesized relationship, and explanatory power of the research model. As presented in Figure 3, the results confirmed all the hypotheses. The $\mathrm{R}^{2}$ values for the dependent variables exceeded 0.1 . The $\mathrm{R}^{2}$ for intention to adopt Fintech was $15.5 \%$, that is, perceived ease of use explained $48.0 \%$, and attachment anxiety explained $19.9 \%$ of intention to adopt Fintech (see Table 6).

Hypotheses 1 to 4 propose that Fintech services belief, Security and Privacy, The Fintech services website design and Fintech services belief positively predict Perceived of ease of use (Hypothesis 1: $\beta$ Fintech services belief $=0.205, \mathrm{p}<0.01$, Hypothesis $2: \beta_{\text {Security and Privacy }}=0.289, \mathrm{p}<$ 0.001 , Hypothesis 3: $\beta$ The Fintech services website design $=0.164, \mathrm{p}<0.05$, Hypothesis $4: \beta_{\text {Costumer value }}=$ $0.260, p<0.001)$. The results show that perceived ease of use positively impacted the intention to adopt fintech, supported Hypothesis 5: $\beta_{\text {Intention to adopt fintech }}=0.592, \mathrm{p}<0.001$ ) (see Table 6).

Table 6

Analysis of competing structural models

\begin{tabular}{|c|c|c|c|c|c|}
\hline Hypotheses & Relationship & $\boldsymbol{\beta}$ & $\begin{array}{c}\mathbf{T}- \\
\text { value }\end{array}$ & $\begin{array}{c}\mathbf{P} \text { - } \\
\text { value }\end{array}$ & Results \\
\hline H1 & $\begin{array}{l}\text { Fintech services belief } \rightarrow \text { Perceived ease to } \\
\text { use }\end{array}$ & 0.205 & 2.882 & 0.004 & Accepted \\
\hline $\mathrm{H} 2$ & Security and privacy $\rightarrow$ Perceived ease to use & 0.289 & 3.493 & 0.000 & Accepted \\
\hline $\mathrm{H} 3$ & $\begin{array}{l}\text { The Fintech services website design } \rightarrow \\
\text { Perceived ease to use }\end{array}$ & 0.164 & 2.155 & 0.003 & Accepted \\
\hline $\mathrm{H} 4$ & Customer value $\rightarrow$ Perceived ease to use & 0.260 & 3.888 & 0.000 & Accepted \\
\hline \multirow[t]{5}{*}{ H5 } & $\begin{array}{l}\text { Perceived ease to use } \rightarrow \text { Intention to adopt } \\
\text { Fintech }\end{array}$ & 0.592 & 11.977 & 0.000 & Accepted \\
\hline & $\mathbf{R}^{2}$ & & & & \\
\hline & $\begin{array}{l}\text { Attachment anxiety by Covid-19 Impact } \\
(19.9 \%)\end{array}$ & & & & \\
\hline & Perceived ease to use $0.48(48.0 \%)$ & & & & \\
\hline & Intention to adopt Fintech 0.155 (15.5\%) & & & & \\
\hline
\end{tabular}

Notes: $\beta$ : Path coefficients sample estimates

Source: Data analysis results

\subsection{Mediating role of attachment anxiety}

The findings confirm that attachment anxiety by Covid-19 Impact positively mediates the effect of on the relationship between perceived ease of use the intention to adopt Fintech, supported Hypothesis $6=0.194, \mathrm{p}<0.001$ ) (see Table 7). 


\section{Table 7}

Mediating effects of the partial mediation model

\section{Bias corrected \\ bootstrap $95 \%$ \\ confidence \\ Result \\ interval}

\begin{tabular}{cccccccc}
\hline Path & $\begin{array}{c}\text { Indirect } \\
\text { effect }\end{array}$ & SE & T-value & $P$-value & Lower & Upper & \\
$\mathrm{EU} \rightarrow \mathrm{AE} \rightarrow \mathrm{IU}$ & 0.194 & 0.197 & 5.583 & 0.000 & 0.135 & 0.272 & Approved \\
\hline
\end{tabular}

Notes: Bootstrapping based on $n=5000$ subsamples AE: Attachment anxiety by Covid-19 Impact; EU: Perceived of ease to use; IU: Intention to adopt Fintech

Source: Data analysis results

\subsection{Multi groups of gender differences}

Specifically, we tested the effect of gender on structural relationships. The path coefficient demonstrates the differences between group 1 and group 2 of gender. According to Partial Least Square Multi-Group Analysis (PLS MGA) probabilities, percentages ( $p$-value) smaller than 0.05 or larger than 0.95 indicate a significant difference in the group-specific PLS path coefficients for the selected relationship (Hair et al., 2016). Gender has no impact on the remaining relationship in the model as the $p$-value of the female and male groups is larger than .05 and smaller than .95 (see Table 8 ).

\section{Table 8}

Path coefficient and $\mathrm{p}$ - values of multi-group analysis between Male and Female

\begin{tabular}{lccl}
\hline & $\begin{array}{c}\text { Path Coefficients - diff } \\
(\mid \text { Female vs Male } \mid)\end{array}$ & $\begin{array}{c}\text { P - Value } \\
(\text { Female vs Male })\end{array}$ & Conclusion \\
\hline $\mathrm{AE} \rightarrow \mathrm{IU}$ & 0.123 & 0.840 & No Difference \\
$\mathrm{CV} \rightarrow \mathrm{EU}$ & 0.092 & 0.715 & No Difference \\
$\mathrm{DE} \rightarrow \mathrm{EU}$ & 0.084 & 0.283 & No Difference \\
$\mathrm{EU} \rightarrow \mathrm{AE}$ & 0.141 & 0.109 & No Difference \\
$\mathrm{EU} \rightarrow \mathrm{IU}$ & 0.132 & 0.178 & No Difference \\
$\mathrm{FS} \rightarrow \mathrm{EU}$ & 0.090 & 0.271 & No Difference \\
\hline
\end{tabular}

Notes: AE: Attachment anxiety by Covid-19 Impact, CV: consumer value, DE: The Fintech services website design; EU: Perceived of ease to use; FS: Fintech services belief; IU: Intention to adopt Fintech; SP: Security and Privacy Source: Data analysis results

\section{Discussion and conclusion}

The results show that within four factors, three factors including Fintech services belief, security, and privacy, the Fintech services website design and customer value positively predict Perceived ease of use have a stronger influence on perceived ease of use than the Fintech services website design. Also, the findings insist ease of use is a significant influence of intention to adopt Fintech. Regarding the mediating role, attachment anxiety strongly impacted the relationship between perceived ease of use and intention to adopt Fintech. The following are the theoretical and practical implications of this study. 


\subsection{Theoretical implication}

This study demonstrates that Covid-19 increases users' use of Fintech. The research results show that the theoretical model of TAM has been extended, especially the factors affecting the perception of ease of use of Fintech, including Fintech's design, realizing that Fintech brings many useful values, benefits for customers, the positive attitude of users to quality, as well as the information security capabilities of Fintech. This is also consistent with previous studies, which have confirmed that security, website, or app design affects the choice of using Fintech (Gai et al., 2016; Kang, 2018; Stewart \& Jürjens, 2018). This study expands on two more factors: the trust of users and the perceived value of consumers also affect the ease of use and intention to use Fintech.

Besides, the results also showed that, due to pandemic, people developed anxiety because of the dangerous situation and did not know when the new epidemic would end (Fu \& Mishra, 2020). They wanted to increase social interactions to reduce anxiety, and Fintech, with its ease of use, spurred the use of the service for everyday shopping and other entertainment needs. Mental health is a problem that is caused by a prolonged lockdown. In addition, the prohibition of movement within one country and between countries causes many families to be separated for a very long time. Furthermore, no one can be sure how long this situation can last. This makes anxiety permanent and creates a feeling of fatigue. So consumers are always trying to find ways to ensure the most normal life, including shopping as a way of interacting with the world around them. Fintech was a powerful tool in the age of the Covid-19 epidemic.

\subsection{Practical implications}

In practical terms, the findings show that the trend of using the service will increase strongly. Locking Covid-19 forces consumers to use Fintech services as a convenient tool to shop and perform financial-related tasks at home. Anxiety during lockdowns and pandemics has become an important positive factor for the rise in Fintech users. This is a great opportunity to contribute to the development potential of Fintech, significantly reducing advertising costs, supporting experiences that not all areas can be in the pandemic. However, to continue to grow and retain users, Fintech services need to focus on other factors that increase the ease of use of Fintech. Specifically, user trust and customer perceived value are two factors that have just been proven in this study. Trust in quality, security, and functionalities used on the Fintech website or app is what keeps users engaged. The manager needs to put great effort into the above factors to increase competitiveness and increase user satisfaction. For example, features need to be easy to use, load quickly, minimize intermediate steps, and automatically verify identity via software. This pushes to another factor, the confidentiality of information. Fintech's infrastructure system needs to be regularly upgraded to ensure the security of the data system. Since these services are related to financial services and bank accounts, confidentiality of information is a prerequisite for users to choose the right service. Combining trust, data security, Fintech services need to increase the attractiveness of the design, emphasize more on the usefulness of the service, as well as the ease of use of Fintech to attract more users. Moreover, to have a superior advantage over the competitors, the above factors need to be paid more attention to. The use of Fintech services in a pandemic is partly understood by the need to shop while pandemic and reduce anxiety by increasing social interaction, such as how to shop. This is an advantage for customers to have a positive experience and a positive attitude to these experiences. So managers see this as an opportunity to increase customer experience. But to maintain the amount of usage, the factors affecting Fintech's trust and ease of use, especially design and customer value, are focused on developing. 


\subsection{Limitations and Future research}

This study has several limitations that could provide effective future research. At first, the data was only collected in Vietnam and at a certain point in time. This creates a limitation related to cultural factors and has not been verified at too many different times. Future studies may carry out data collection overtime series to increase the representativeness of the results. The study can also take data from different cultures to be able to see the differences in the impact factors. Finally, future research should compare differences in technology accessibility to regular use of Fintech services. Since then, Fintech can develop tools suitable for all subjects, increasing the amount of use.

\section{DECLARATION OF INTERESTS} article.

The authors declare no competing interests. This text will be published alongside your

\section{References}

Aladwani, A. (2006). An empirical test of the link between website quality and forward enterprise integration with web consumers. Business Process Management Journal, 12(2), 178-190. doi:10.1108/14637150610657521

Alalwan, A., Dwivedi, Y., Rana, N., \& Williams, M. (2016). Consumer adoption of mobile banking in Jordan: Examining the role of usefulness, ease of use, perceived risk and selfefficacy. Journal of Enterprise Information Management, 29(1), 118-139. doi:10.1108/JEIM-04-2015-0035

Asian Development Bank. (2019). Fintech for Asian smes. Asian development bank institute. Retrieved May 20, 2019, from https://www.adb.org/publications/fintech-for-smes

Augeraud, E., Banerjee, M., Dhersin, J. S., D’Onofrio, A., Lipniacki, T., Petrovskii, S., ... Turinici, G. (2020). Heterogeneous social interactions and the Covid-19 lockdown outcome in a multi-group seir model. Mathematical Modelling of Natural Phenomena, 15(36), 1-18. doi:10.1051/mmnp/2020025

Asyhari, A., Pudjihastuti, S. H., \& Marhaeni, D. (2018). Peran mediasi keunggulan kompetitif pada faktor determinan kinerja bisnis ukm di sentra tenun batik di jawa tengah. Jurnal Siasat Bisnis, 22(2), 111. doi:10.20885/jsb.vol22.iss2.art1

Barth, S., de Jong, M. D. T., Junger, M., Hartel, P. H., \& Roppelt, J. C. (2019). Putting the privacy paradox to the test: Online privacy and security behaviors among users with technical knowledge, privacy awareness, and financial resources. Telematics and Informatics, 41, 55-69. doi:10.1016/j.tele.2019.03.003

Bauer, H., Falk, T., \& Hammerschmidt, M. (2006). eTransQual: A transaction process-based approach for capturing service quality in online shopping. Journal of Business Research, 59(7), 866-875. doi:10.1016/j.jbusres.2006.01.021

Bentler, P. M., \& Bonett, D. G. (1980). Significance tests and goodness of fit in the analysis of covariance structures. Psychological Bulletin, 88(3), 588-606. doi:10.1037/00332909.88.3.588

Billore, S., \& Billore, G. (2020). Consumption switch at haste: insights from Indian low-income customers for adopting Fintech services due to the pandemic. Transnational Marketing Journal, 8(2), 197-218. 
Blut, M. (2016). E- service quality: Development of a hierarchical model. Journal of Retailing, 92(4), 500-517. doi:10.1016/j.jretai.2016.09.002

Cao, X., \& Sun, J. (2018). Exploring the effect of overload on the discontinuous intention of social media users: An s-o-r perspective. Computers in Human Behavior, 81, 10-18. doi:10.1016/j.chb.2017.11.035

Chou, W.-P., Wang, P.-W., Chen, S.-L., Chang, Y.-P., Wu, C.-F., Lu, W.-H., \& Yen, C.-F. (2020). Risk perception, protective behaviors, and general anxiety during the coronavirus disease 2019 pandemic among affiliated health care professionals in taiwan: Comparisons with frontline health care professionals and the general public. International Journal of Environmental Research and Public Health, 17(24), 1-11. doi:10.3390/ijerph17249329

Chuang, L. M., Liu, C. C., \& Kao, H. K. (2016). The adoption of fintech service: TAM perspective. International Journal of Management and Administrative Sciences, 3(7), 1-15.

Collins, N., \& Read, S. (1990). Adult attachment, working models, and relationship quality in dating couples. Journal of Personality and Social Psychology, 58(4), 644-663. doi:10.1037/0022-3514.58.4.644

Daqar, M. A., Constantinovits, M., Arqawi, S., \& Daragmeh, A. (2021). The role of Fintech in predicting the spread of Covid-19. Banks and Bank Systems, 16(1), 1-16. doi:10.21511/bbs.16(1).2021.01

Darmansyah, D., Fianto, B. A., Hendratmi, A., \& Aziz, P. F. (2020). Factors determining behavioral intentions to use islamic financial technology: Three competing models. Journal of Islamic Marketing, 12(4), 794-812. doi:10.1108/JIMA-12-2019-0252

Davis, F. D. (1989). Perceived usefulness, perceived ease of use, and user acceptance of information technology. MIS Quarterly, 13(3), 319-340. doi:10.2307/249008

Davis, F. D., Bagozzi, R. P., \& Warshaw, P. R. (1989). User acceptance of computer technology: A comparison of two theoretical models. Management Science, 35(8), 982-1003.

DeLone, W. H., \& McLean, E. R. (2003). The DeLone and McLean model of information systems success: a ten-year update. Journal of Management Information Systems, 19(4), 9-30.

Dennis, C., Merrilees, B., Jayawardhena, C., \& Tiu Wright, L. (2009). E-consumer behaviour. European Journal of Marketing, 43(9/10), 1121-1139. doi:10.1108/03090560910976393

Dickinger, A., \& Stangl, B. (2013). Website performance and behavioral consequences: A formative measurement approach. Journal of Business Research, 66(6), 771-777.

Dolbeault, J., \& Turinici, G. (2020). Heterogeneous social interactions and the Covid-19 lockdown outcome in a multi-group seir model. Mathematical Modelling of Natural Phenomena, 15, Article 36. doi:10.1051/mmnp/2020025

Eastwick, P. W., \& Finkel, E. J. (2008). The attachment system in fledgling relationships: An activating role for attachment anxiety. Journal of Personality and Social Psychology, 95(3), 628-647. doi:10.1037/0022-3514.95.3.628

Fornell, C., \& Larcker, D. F. (1981). Structural equation models with unobservable variables and measurement error: Algebra and statistics. Journal of Marketing Research, 18(3), 382-388. doi:10.1177/002224378101800313 
Fu, J., \& Mishra, M. (2020). Fintech in the time of Covid-19: Trust and technological adoption during crises. Swiss Finance Institute Research Paper, 20-38. doi:10.2139/ssrn.3588453

Gai, K., Qiu, M., Sun, X., \& Zhao, H. (2016, December). Security and privacy issues: A survey on FinTech. In International Conference on Smart Computing and Communication (pp. 236-247). Cham, NY: Springer.

Gerbing, D. W., \& Anderson, J. C. (1992). Monte carlo evaluations of goodness of fit indices for structural equation models. Sociological Methods \& Research, 21(2), 132-160. doi:10.1177/0049124192021002002

Gerrard, P., \& Cunningham, J. B. (2003). The diffusion of internet banking among singapore consumers. International Journal of Bank Marketing, 21(1), 16-28. doi:10.1108/02652320310457776

Hair, J. F. (2019). Multivariate data analysis (8th ed.). Hampshire, UK: Cengage.

Hair, J. F. (2014). A primer on partial least squares structural equation modeling (pls-sem). Thousand Oaks, CA: SAGE Publications.

Hair, J. F., Sarstedt, M., Hopkins, L., \& Kuppelwieser, V. G. (2014). Partial Least Squares Structural Equation Modeling (PLS-SEM): An emerging tool in business research. European Business Review, 26(2), 106-121. doi:10.1108/EBR-10-2013-0128

Hair, J., Sarstedt, M., Matthews, L. M., \& Ringle, C. M. (2016). Identifying and treating unobserved heterogeneity with FIMIX-PLS: part I - method. European Business Review, 28(1), 63-76. https://doi.org/10.1108/EBR-09-2015-0094

Henseler, J., Ringle, C., \& Sarstedt, M. (2015). A new criterion for assessing discriminant validity in variance-based structural equation modeling. Journal of the Academy of Marketing Science, 43(1), 115-135. doi:10.1007/s11747-014-0403-8

Horváth, C., \& Adigüzel, F. (2018). Shopping enjoyment to the extreme: Hedonic shopping motivations and compulsive buying in developed and emerging markets. Journal of Business Research, 86(5), 300-310. doi:10.1016/j.jbusres.2017.07.013

Howcroft, B., Hamilton, R., \& Hewer, P. (2002). Consumer attitude and the usage and adoption of home based banking in the united kingdom. International Journal of Bank Marketing, 20(3), 111-121.

Huei, C. T., Cheng, L. S., Seong, L. C., Khin, A. A., \& Bin, R. L. L. (2018). Preliminary Study on consumer attitude towards FinTech products and services in Malaysia. International Journal of Engineering \& Technology, 7, 166-169.

Irons, C., \& Gilbert, P. (2005). Evolved mechanisms in adolescent anxiety and depression symptoms: The role of the attachment and social rank systems. Journal of Adolescence, 28(3), 325-341.

Isaac, M. S., Brough, A. R., \& Grayson, K. (2016). Is top 10 better than top 9? The role of expectations in consumer response to imprecise rank claims. Journal of Marketing Research, 53(3), 338-353. doi:10.1509/jmr.14.0379

Jayawardhena, C., \& Wright, L. T. (2009). An empirical investigation into e-shopping excitement: antecedents and effects. European Journal of Marketing, 43(9/10), 1171-1187. doi:10.1108/03090560910976429 
Jiwasiddi, A., Adhikara, C., Adam, M., \& Triana, I. (2019). Attitude toward using Fintech among Millennials. In The 1st Workshop on Multimedia Education, Learning, Assessment and Its Implementation in Game and Gamification in Conjunction with COMDEV 2018. doi:10.4108/eai.26-1-2019.2283199

Joseph, M., \& Stone, G. (2003). An empirical evaluation of US bank customer perceptions of the impact of technology on service delivery in the banking sector. International Journal of Retail \& Distribution Management, 31(4), 190-202. doi:10.1108/09590550310469185

Joseph, M., McClure, C., \& Joseph, B. (1999). Service quality in the banking sector: The impact of technology on service delivery. International Journal of Bank Marketing, 17(4), 182-193.

Kang, J. (2018). Mobile payment in Fintech environment: Trends, security challenges, and services. Human-Centric Computing and Information Sciences, 8(1), 1-16. doi:10.1186/s 13673-018-0155-4

Karjaluoto, H., Mattila, M., \& Pento, T. (2002). Factors underlying attitude formation towards online banking in Finland. International Journal of Bank Marketing, 20(6), 261-272. doi:10.1108/02652320210446724

Kim, D. (2019). "How do you feel about a disease?" The effect of psychological distance towards a disease on health communication. International Journal of Advertising, 38(1), 139-153. doi:10.1080/02650487.2018.1438031

Kim, H., Lee, J., Mun, J., \& Johnson, K. (2017). Consumer adoption of smart in-store technology: Assessing the predictive value of attitude versus beliefs in the technology acceptance model. International Journal of Fashion Design, Technology and Education, 10(1), 26-36. doi:10.1080/17543266.2016.1177737

Lai, A. W. (1995). Consumer values, product benefits and customer value: a consumption behavior approach. ACR North American Advances, 22(6), 381-388.

Lee, C., Li, X., Yu, C., \& Zhao, J. (2021). Does fintech innovation improve bank efficiency? Evidence from China's banking industry. International Review of Economics \& Finance, 74(4), 468-483. doi:10.1016/j.iref.2021.03.009

Lee, Y., Park, J., Chung, N., \& Blakeney, A. (2012). A unified perspective on the factors influencing usage intention toward mobile financial services. Journal of Business Research, 65(11), 1590-1599. doi:10.1016/j.jbusres.2011.02.044

Lee, J., Ryu, M., \& Lee, D. (2019). A study on the reciprocal relationship between user perception and retailer perception on platform-based mobile payment service. Journal of Retailing and Consumer Services, 48(C), 7-15. doi:10.1016/j.jretconser.2019.01.007

Li, G., Dai, J., Park, E., \& Park, S. (2017). A study on the service and trend of Fintech security based on text-mining: Focused on the data of Korean online news. Journal of Computer Virology and Hacking Techniques, 13(4), 249-255. doi:10.1007/s11416-016-0288-9

Nguyen, L. T. K., Doan, T. T. T., \& Bui, T. N. (2020). Fintech and banking: Evidence from Vietnam. The Journal of Asian Finance, Economics, and Business, 7(9), 419-426. doi:10.13106/JAFEB.2020.VOL7.NO9.419

Lim, S., Kim, D., Hur, Y., \& Park, K. (2019). An empirical study of the impacts of perceived security and knowledge on continuous intention to use mobile fintech payment services. International Journal of Human-Computer Interaction, 35(10), 886-898. doi:10.1080/10447318.2018.1507132 
Liu, Q., Yang, X., Zhu, X., \& Zhang, D. (2019). Attachment anxiety, loneliness, rumination and mobile phone dependence: A cross-sectional analysis of a moderated mediation model. Current Psychology (New Brunswick, N.J.), 1(11). doi:10.1007/s12144-019-00464-X

Luchetti, M., Lee, J., Aschwanden, D., Sesker, A., Strickhouser, J., Terracciano, A., \& Sutin, A. (2020). The trajectory of loneliness in response to Covid-19. The American Psychologist, 75(7), 897-908. doi:10.1037/amp0000690

Maes, J., Leroy, H., \& Sels, L. (2014) Gender differences in entrepreneurial intentions: A tpb multi-group analysis at factor and indicator level. European Management Journal, 32(5), 784-794.

Mariño-Mesías, R., Rodríguez-Antón, J., \& Rubio-Andrada, L. (2015). How does human capital influence service quality? An application to the Andorran banking sector. Revista Española De Financiación Y Contabilidad, 44(2), 146-179. doi:10.1080/02102412.2014.991126

Moutinho, L., \& Smith, A. (2000). Modelling bank customer satisfaction through mediation of attitudes towards human and automated banking. International Journal of Bank Marketing, $18(3), 124-134$.

Nangin, M. A., Barus, I. R. G., \& Wahyoedi, S. (2020). The effects of perceived ease of use, security, and promotion on trust and its implications on fintech adoption. Journal of Consumer Sciences, 5(2), 124-138.

Persaud, A., \& Azhar, I. (2012). Innovative mobile marketing via smartphones: Are consumers ready? Marketing Intelligence \& Planning, 30(4), 418-443. doi:10.1108/02634501211231883

Peteet, J. R. (2020). Covid-19 anxiety. Journal of Religion and Health, 59(5), 2203-2204.

Podsakoff, P. M., MacKenzie, S. B., Lee, J.-Y., \& Podsakoff, N. P. (2003). Common method biases in behavioral research: A critical review of the literature and recommended remedies. Journal of Applied Psychology, 88(5), 879-903. doi:10.1037/00219010.88.5.879

Ponte, E. B., Carvajal-Trujillo, E., \& Escobar-Rodríguez, T. (2015). Influence of trust and perceived value on the intention to purchase travel online: Integrating the effects of assurance on trust antecedents. Tourism Management, 47(2), 286-302.

Prati, G., \& Mancini, A. (2021). The psychological impact of Covid-19 pandemic lockdowns: A review and meta-analysis of longitudinal studies and natural experiments. Psychological Medicine, 51(2), 201-211. doi:10.1017/S0033291721000015

Revathy, C., \& Balaji, P. (2020). Determinants of behavioural intention on e-wallet usage: An empirical examination in amid of Covid-19 lockdown period. International Journal of Management (IJM), 11(6), 92-104.

Rodríguez-Hidalgo, A., Pantaleón, Y., Dios, I., \& Falla, D. (2020). Fear of Covid-19, stress, and anxiety in university undergraduate students: A predictive model for depression. Frontiers in Psychology, 11(3), 591797-591797. doi:10.3389/fpsyg.2020.591797

Rubin, K. H., Coplan, R. J., \& Bowker, J. C. (2009). Social withdrawal in childhood. Annual Review of Psychology, 60(1), 141-171. doi:10.1146/annurev.psych.60.110707.163642 
Saadé, R., \& Kira, D. (2007). Mediating the impact of technology usage on perceived ease of use by anxiety. Computers and Education, 49(4), 1189-1204. doi:10.1016/j.compedu.2006.01.009

Simpson, J., Rholes, W., \& Nelligan, J. (1992). Support seeking and support giving within couples in an anxiety-provoking situation: The role of attachment styles. Journal of Personality and Social Psychology, 62(3), 434-446. doi:10.1037/0022-3514.62.3.434

Singh, S., Sahni, M., \& Kovid, R. (2020). What drives FinTech adoption? A multi-method evaluation using an adapted technology acceptance model. Management Decision, 58(8), 1675-1697. doi:10.1108/MD-09-2019-1318

Sirdeshmukh, D., Singh, J., \& Sabol, B. (2002). Consumer trust, value, and loyalty in relational exchanges. Journal of Marketing, 66(1), 15-37.

Sreejesh, S., \& Roy, S. (2015). A new consumer brand relationships framework. In Consumer brand relationships (pp. 165-197). London, UK: Palgrave Macmillan.

Stewart, H., \& Jürjens, J. (2018). Data security and consumer trust in FinTech innovation in Germany. Information Management \& Computer Security, 26(1), 109-128. doi:10.1108/ICS-06-2017-0039

Sweeney, J., \& Soutar, G. (2001). Consumer perceived value: The development of a multiple item scale. Journal of Retailing, 77(2), 203-220. doi:10.1016/S0022-4359(01)00041-0

Talwar, S., Dhir, A., Khalil, A., Mohan, G., \& Islam, A. (2020). Point of adoption and beyond. Initial trust and mobile-payment continuation intention. Journal of Retailing and Consumer Services, 55(4), Article 102086. doi:10.1016/j.jretconser.2020.102086

Trivedi, R., Patel, J., \& Acharya, N. (2018). Causality analysis of media influence on environmental attitude, intention and behaviors leading to green purchasing. Journal of Cleaner Production, 196(25), 11-22. doi:10.1016/j.jclepro.2018.06.024

Venkatesh, V. (2000). Determinants of perceived ease of use: Integrating control, intrinsic motivation, and emotion into the technology acceptance model. Information Systems Research, 11(4), 342-365.

Vučinić, M. (2020). Fintech and financial stability potential influence of Fintech on financial stability, risks and benefits. Journal of Central Banking Theory and Practice (Podgorica), 9(2), 43-66. doi:10.2478/jcbtp-2020-0013

Wójcik, D., \& Ioannou, S. (2020). Covid-19 and finance: Market developments so far and potential impacts on the financial sector and centres. Tijdschrift Voor Economische En Sociale Geografie, 111(3), 387-400. doi:10.1111/tesg.12434

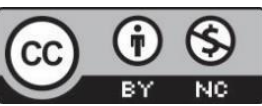

Creative Commons Attribution-NonCommercial 4.0 International License. 